\title{
Migrant Workers as Marginalized People in Taiwan: A Reflection from Contextual Theology
}

\author{
Ya-Tang Chuang*
}

\begin{abstract}
Migrant workers are marginalized and suffering people in Taiwan at present-day. There are discussions about issue of migrant worker from economical, legal, political and cultural perspectives, but rarely from religious aspects. In this paper, the author intends to approach it from the aspect of contextual theology. Firstly, the author would analyze the marginalized situations of migrant workers in Taiwan. In a sense, they are what contextual theologian identified as marginalized and suffering people or so called "minjung." Secondly, the author would observe how Christian churches and institutes respond to the plight of migrant workers by practicing missio Dei. Thirdly, the author would reflect the theological meaning of migrant workers by interpreting the biblical texts and the parable of Jesus concerning the kingdom of God, and point out to do justly, to be compassionate and to practice hospitality to migrant workers are imperative of social ethics of Christians at present-day.
\end{abstract}

Key-words: migrant workers, contextual theology, marginalized, hospitality, missio Dei

\section{Trabalhadores imigrantes como pessoas marginalizadas em Taiwan: uma reflexão da Teologia Contextual}

\section{Resumo}

Os trabalhadores migrantes são marginalizados e sofrem atualmente em Taiwan. Há discussões sobre a questão do trabalhador migrante de acordo com perspectivas econômicas, legais, políticas e culturais, mas raramente segundo os aspectos religiosos. Neste trabalho, o autor pretende abordar essa questão a partir do aspecto da teologia contextual. Em primeiro lugar, o autor procura analisar as situações marginalizadas dos trabalhadores migrantes em Taiwan. Em certo sentido, eles são o que o teólogo contextual identificou como pessoas marginalizadas e sofredoras ou chamadas de "minjung". Em segundo lugar, o autor procura observar como as igrejas e organizações cristãos respondem ao sofrimento dos trabalhadores migrantes, praticando Missio Dei. Em terceiro lugar, o autor procura refletir o significado teológico dos trabalhadores migrantes, interpretando os textos bíblicos e a parábola de Jesus a

* Chang Jung Christian University. 
respeito do reino de Deus, e sinalizando que fazer justiça, ser compassivo e praticar a hospitalidade aos trabalhadores migrantes são imperativos da ética social dos cristãos nos dias de hoje.

Palavras-chave: trabalhadores migrantes, teologia contextual, marginalizados, hospitalidade, Missio Dei.

\section{Los trabajadores migrantes como personas marginadas en Taiwán: una reflexión desde la teología contextual}

\section{Resumen}

En la actualidad los trabajadores migrantes sufren y son marginados en Taiwan. Existen acercamientos al tema del trabajador migrante desde perspectivas económicas, legales, políticas y culturales, pero rara vez desde aspectos religiosos. En este artículo, el autor pretende abordar el fenómeno desde la teología contextual. En primer lugar, el autor va analizar las situaciones marginadas de los trabajadores migrantes en Taiwán. En cierto sentido, son lo que los teólogos contextuales identificaron como personas marginadas y sufrientes, o el llamado "minjung". En segundo lugar, va observar cómo las iglesias e institutos cristianos responden a la difícil situación de los trabajadores migrantes practicando missio Dei. En tercer lugar, expondrá el significado teológico de los trabajadores migrantes al interpretar los textos bíblicos y la parábola de Jesús sobre el reino de Dios, y señala que ser justos, ser compasivos y practicar la hospitalidad a los trabajadores migrantes es un imperativo de la ética social de los cristianos en la actualidad.

Palabras clave: trabajadores migrantes, teología contextual, marginados, hospitalidad, missio Dei.

One famous riot and two incidents happened recently reveal the miserable situations of migrant workers as marginalized people in the civil society of Taiwan.

On 21 August 2005, around 300 of a group of 1,700 Thai migrant workers building the Kaohsiung Rapid Transit Corp revolted against the manpower agency, which was appointed by the construction firm to hire and supervise migrant workers. This was the biggest riot caused by migrant workers in Taiwan. Migrant workers could not bear anymore of poor treatment, the inhumane management, the harsh living conditions, and the illegally charged brokerage fees. This riot unmasked also the corruption of political power manipulated behind the migrant workers. ${ }^{1}$

On 20 May 2016, a group of 81 migrant workers (fishermen) were found to have been "kept like slaves" in a building during non-working

More detailed report, see “KRTC Scandal: Workers' riot ends up reshaping politics" in Taipei News website: http://www.taipeitimes.com/News/taiwan/ archives/2005/11/07/2003279103 accessed 16 June 2018. 
times by their Taiwanese employers. This group of foreign fishermen had been paid each between 300 and 500 USD monthly for working 48 hours a week, much below the 750 USD they should have been paid as a minimum wage and much over the 40 hours workweek that is legally stipulated by law. They were kept in a very simple and crude building, doors were locked, windows were sealed. They shared one restroom while oversighted by many monitors. It's reported that "they are treated worse than the prisons, even worse than dogs." 2

On 31 August 2017, A 27-year-old Vietnamese Nguyen Quoc Phi, a "runaway" migrant worker who was reported a car theft, was shot nine times by police and was dead soon because Taiwanese paramedics did not offer him any aid. ${ }^{3}$

These three and other similar stories display the suffering and marginalized situations of migrant workers in Taiwan. In fact, they are marginalized much more than the aboriginal people of Taiwan, and suffered much more than domestic workers.

\section{Marginalized Conditions of Migrant Workers in Taiwan}

According to the "International Convention for the Protection of the Rights of All Migrant Workers and Members of their Families" (ICRMW) a migrant worker is "a person who is to be engaged, is engaged or has been engaged in a remunerated activity in a State of which he or she is not a national." 4

2 More detailed report of this incident, see South China Morning Post, published on 20 September, 2017 http://www.scmp.com/news/china/policies-politics/article/2111965/ group-fishermen-kept-slaves-taiwan, accessed 14 June 2018.

3 More detailed report of this incident, see $\boldsymbol{B} \boldsymbol{B} \boldsymbol{C}$ News published on 17 September 2017, https://www.bbc.com/news/world-asia-41298076, accessed June 16, 2018. "Runaway" is always a difficult problem to deal with. For example, in 2017, the average of 'runaway' migrant workers in Taiwan is 18209 persons, $2.3 \%$ of the total. Lan Anh Hoang analyzed the he prevalence of runaway is closely related to the absence of organized forms of power and resistance. See Lan Anh Hoang, Moral Dilemmas of Transnational Migration: Vietnamese Women in Taiwan. In Gender and Society (2016) Vol.30, No.6, pp. 890-911.

4 Article 2 of the Convention. See Migration and Human Rights: The United Nations Convention on Migrant Workers' Rights, edited by Ryszard Cholewinski, et al., (Cambridge University Press, 2009). This definition is very broad - even if it excludes refugees - as all aliens resident in a country are likely to have worked or to work in the future and are therefore potentially included. 
Look back to the history of Taiwan, we learn that Taiwan was once an "promised" island for migrant workers from ancient China. There were a lot of migrant workers, one group after another, sailed cross the Taiwan strait, in spite of dangers and difficulties, to Taiwan Island for survival. Most of two of biggest ethnic groups of Taiwanese today, Hô-ló and Hakka, are decedents of these migrant workers. It is not exaggerated to say that migrant worker impelled the historical development of Taiwan. This trend of migrant workers was banned and extinct because of colonialism of Japan (1895-1945) and the political animosity between Taiwan Authority and Communist China after 1949.

Until 1989, migrant workers come to Taiwan again, and this time, they were introduced by the Taiwanese Government for the development of economic growth. As we know, migrant worker is a popular phenomenon in the age of neo-liberal globalization. It is estimated that over 213 million migrants have been cross national borders annually, with a significant flow from the Global South to Northern capitalist advanced regions. ${ }^{5}$ The issue of migrant worker in Taiwan is only a miniature of the whole picture in the neo-liberal globalization.

Migrant workers in Taiwan come mainly from four counties: Philippines, Thailand, Vietnam and Indonesia. According to the latest statistics made by Ministry of Labor of Taiwanese government in the end of April 2018, the grand total of migrant worker is 683,387. Among them, Indonesian is $260,594(38.13 \%)$, Vietnam $210,976(30.87 \%)^{6}$; Philippines 151,071 (22.10\%), and Thailand 60,754, $(0.08 \%) .{ }^{7} \mathrm{Up}$ to the end of April 2018 , the total of domestic workers is $11,727,000$. That means relative to every 16 domestic workers, there is 1 migrant worker in the labor market

5 Item "The age and sex of migrants 2011" in United Nations Population Division. Cited from Wen Liu, The embodied crises of neoliberal globalization: The lives and narratives of Filipina migrant domestic workers. In Women's Studies International Forum (2015) Vol.50, 80-88, p.80.

6 Except those who are "documented", they also illegal migrant workers. Most of them are from Vietnam. It is estimated that at least 26,000 Vietnamese workers in Taiwan are illegal. See, "New documentary unveils the life of Vietnamese migrant workers in Taiwan." Taiwan News, March 20, 2018. https://www.taiwannews.com.tw/en/news/3386443, accessed 10 June 2018.

7 See, "Table of Workers in Productive Industries and Social Welfare by Nationality," Workforce Development Agency, Ministry of Labor, Taiwan. http://statdb.mol.gov.tw/statis/ jspProxy.aspx? sys $=220 \& y \mathrm{~m}=10504 \& \mathrm{ymt}=10704 \& \mathrm{kind}=21 \&$ type $=1 \&$ funid $=\mathrm{q} 13012 \&$ cycle $=$ 41 \&outmode $=0 \& \&$ compmode $=0$ \&outkind $=11 \& \mathrm{fldspc}=0,8, \& \mathrm{rdm}=\mathrm{V} 4 \mathrm{nVIjtg} /$ Accessed 6 June 62018. 
of Taiwan. Today, the number of migrant workers in Taiwan is more than that of aboriginal people which is totally about 540,000. For a long time, aboriginal people was marginalized, but fortunately their situation was improved by the Taiwan's government. Compare to inside Taiwanese aboriginal people, migrant workers from outside are much more marginalized.

The working conditions of migrant worker are described as "3D" + "1 L": difficult, dangerous, dirty work and low paid. In Taiwan, the basic monthly salary is 22,000 NTD (about 745 750 UDS) at present-day. Many migrant workers are paid less than this minimum standard. Besides, they have to pay broker fees both to brokers in Taiwan and in their own country. Double broker fees mean double exploitation. According to investigation, the broker fees of migrant worker in Taiwan are the highest in Asia. ${ }^{8}$

The policy concerning the identity of migrant worker is very unfavorable to them. It defines migrant worker as temporary "Tai-ker" (literal means guest-worker) to fill the vacancy of domestic labor. It excludes totally the possibility of any migrant worker to be naturalized into Taiwanese by his/ her long-term service in Taiwan. This policy enables the government "and its collaborators work together to enhance the control capacity over migrants, while at the same time, enabling the state to keep its liberal pretense." (TSENG \& HONG, 2013, p. 1) In this "guestworker schemes that pay special attention to preventing guestworkers from staying, the government treats migrant workers like water, and is likely to design a faucet to turn the flow on or off at will. However, such a process, as is the case in Taiwan, is in opposition with some important values treasured by democratic societies, among them being freewill based decision-making." (TSENG \& HONG, 2013, p. 15) It is very difficult for migrant workers, who constrained tightly by this scheme, to form any permanent community for their own benefits and rights. In the society of Taiwan, migrant workers are always the "objects" to be decided by the government, broker agency and employer, and never play the role of "subjects" who can decide for themselves. Their "subjectivity" - the root of dignity, are exploited and they are "objectified" and "marginalized."

\footnotetext{
8 It is estimated that a migrant work has to pay $90,000 \sim 220,000 \mathrm{NTD}$, about 5 to 14 monthly salary. Migrant workers from Indonesia have to loan from bank about 50,000 NTD to pay the broker fee before they come to Taiwan. The interest is $19 \%$ high. Most of migrant workers have to their salary of first year to broker fee. High broker fee is the most powerful weapon to control them.
} 
Another policy is also unfavorable to migrant worker. It demands the employers responsible for "managing" the lives and activities of migrant workers. In case a migrant worker run away, his/her employer will be punished by the government. ${ }^{9}$ Therefore, their passports and resident permit certificates are detained, their outside activities in free time are controlled by their employers. Some migrant workers were banned to attend religious activities. Muslim migrant workers are very difficult to practice their faith not only because few mosques in Taiwan but also the prohibition of their employers.

According to one result of interview, $73 \%$ interviewed migrant workers felt that they were discriminated in Taiwan. (YANG \& SHIH, 1999, pp. 93107 , here translation is mine) This interview was made in 1999, the situation at present-days might have been improved, but the basic attitude of Taiwanese to migrant workers did not change significantly. Taiwanese are very friendly to foreign visitors, especially from Western countries and Japan, but their attitude to migrant workers from Asian countries is quite different.

Allison Lee, ${ }^{10}$ the founder of the first Migrant Fishermen Union of Taiwan in 2013, documented hundreds of accounts of exploitation, abuse, forced labor and underpayment, human trafficking of migrant fisherman in Taiwan. Jing Ru Wu, the chairperson of Taiwan International Worker Association (TIWA), said in an interview, "migrant workers are what we call the 'modern slavery' in Taiwan. They don't have freedom to transfer employer, they have to have lots of debt to before they can come to Taiwan to work (paying brokers). They have no legal protection and all their rights are very restricted." ${ }^{11}$ Both of them, based on their long-term experience, witness the plight of migrant workers.

In sum up, migrant workers in Taiwan are marginalized people and suffered in many dimensions. They are identified as "guest workers" by the government, exploited by brokers of both sides (Taiwan and their

9 In Taiwan, the governance of migrant workers was shifted from the hand of state to the private sector. This shift was conceptualized as "privatization of governance." See, Tseng, Yen-fen \& Hong-zen Wang, Governing Migrant Workers at a Distance: Managing the Temporary Status of Guestworkers in Taiwan, in International Migration (2013), Vo.51, No. 4: 1-19, pp. 12-13.

10 See profile of Allison Lee, in National Underground Railroad Freedom Center, USA. Cited from http://www.tipheroes.org/allison-lee/ accessed 15 June 2018.

11 See, "Migrant workers right in Taiwan: An Interview with The Taiwan International Workers Association" (TIWA). In the Blog, Nihao's Going, https://nihaositgoing. com/2017/11/07/migrant-worker-rights-in-taiwan-an-interview-with-the-taiwaninternational-workers-association-tiwa/ accessed 16 June 2018. 
own country), discriminated by citizen and excluded by the society. They are cheapest labor in Taiwan, and work very hard in the harsh working environments. Sometimes they were blamed as the culprits of the rising unemployment, sometimes they become the scapegoats of social problems. Their lives are very cheap, and their dignity is ignored. They are what Choan-Seng Song ${ }^{12}$, famous contextual theologian of Taiwan, described as the suffering people who "are oppressed, exploited, disadvantaged, and marginalized, socially, politically, economically, culturally, and also religiously." (SONG, 1990, pp. 215-216) Or in the words of Minjung theology of Korea, they are "minjung" with no identity, no social status, no human rights, and are excluded and marginalized in the society. (MOON, 1985, p. 1)

\section{Churches' Ministry for Migrant Workers}

In 1990, the United Nations (UN) General Assembly adopted "The International Convention on the Protection of the Rights of All Migrant Workers and Members of Their Families" (ICRMW), the most comprehensive international treaty in the field of migration and human rights. However, even it already entered into force on 1 July 2003, most countries are reluctant to ratify this treaty. ${ }^{13}$ Obviously, there is a "sharping clashes between the conditions of globalization and a rights based approach to governance" (TARAN, 2009, p. 151) of migrant workers.

Taiwan, being not a member country of the UN, has no question to ratify this treaty or not. But as we discussed above, the governance of migrant workers in Taiwan has much to be improved. Fortunately, Christian Churches (both of Catholic and Protestant) and church-related institutes (centers) began their ministry to migrant workers. Although there are some active NGOs concerns the issue of migrant worker, the Christian Churches are the most steadfast and next-working organization in protecting the rights and implementing the welfares of migrant workers.

In the earlier stage most migrant workers came from Philippines, later on Vietnamese increased. Both Philippine and Vietnam were strongly influenced by Catholic Church. This is the reason why Catholic Church started her ministry

12 Choan-Seng Song (1929 ) is a Distinguished Professor Emeritus of Theology and Asian Cultures at the Pacific School of Religion. He was principal of Tainan Theological College (1965-70) and, later, president of the World Alliance of Reformed Churches (19772004). He is regarded one of pioneering theologians of Asia, became famous because his story theology. He was honored as a "guru of story theology."

13 General Assembly Resolution 45/158 of 18 December 1990. 
migrant workers earlier than Protestant Church. As a universal religion, Catholic Church had concerned the issue of migrant workers in many countries and for a long time. Pope John Paul II declared, "To care migrant workers is the way to achieve the mission of the church today." 14

There are many institutes related or affiliated to Catholic Church in different cities and towns of Taiwan have ministry for migrant workers: Taipei Archdiocesan Pastoral Care of Migrant Worker, also called Migrant Workers' Concern Desk (MWCD); Rerum Novarum Center; St. Christopher Church Migrant Workers' Centre; Consultation Center for Philippine Workers in Taiwan; Good Shepherd Sister Social Welfare Services Foundation; Immaculate Heart of Mary Church; Catholic Hope Workers Center; Hsin-Chu Migrants' Concern Desk; Holy Family Church; Tai Chung Pastoral Center for Filipino Migrant; Kaohsiung Stella Maris International Service Center; CARITAS-Taiwan; and Taiwan International Migrants Mission (TIMM).

Protestant Church in Taiwan (including of different denominations) is also active today in doing ministry for migrant workers. Among many churchrelated institutes, Industrial Evangelical Missions(IEM) and Care Center for Labor, Presbyterian Church in Taiwan (PCT) are the two biggest ones. In addition to them, Tan-zu Gospel Center, Shin-chu Lutheran Seminary, Suan Siam Thai Gospel Center of Chia-Yi Christian Hospital, Thai-Family in different cities and towns. ${ }^{15}$ Thai-Families are for ministry for Thai migrant workers only, for Indonesian migrant workers there are PELITA ( Peduli Imigran \& Tenaga Kerja Indonesia), Industrial Evangelical Centre in Chongli and K-PACT International. ${ }^{16}$

\footnotetext{
14 According to Pope John Paul II, "Address on the $87^{\text {th }}$ Day of International Migrant Worker.”( 2001) Cited from http://www.hkjp.org/files/files/focus/ humanright/2001_87\%27_immigrant_\%20refugee_\%20statement.pdf. Accessed 10 January 2018. Here translation is mine.

15 Names of these Cities: Taichung, Pintung. Names of these towns: Sanchong, Shulin, Nankan Neili, Chongli, Kuanen, Shinfeng. It is meaningful that the ministry is in towns as well as in cities.

16 K-PACT International an international NGO. K means "Seeking first His Kingdom and His righteousness." P means "Provide food, medical, and educational services." A means "Assist local Christians to enrich their life in their faith." $\mathbf{C}$ means "Create business opportunities with job trainings." T means "Train Christian men and women into full-time ministry." K-PACT has offices in USA, Indonesia and Hong Kong to support the ministry for Indonesian around the world. For more information, see the website of K-PACT at https://kpactinternational.wordpress.com.
} 
It noteworthy that "Home", "Family", "Bridge" are metaphors used in Church's ministry for migrant workers. To offer a family-like place for those migrant workers is important for their body and soul. Those centers for Indonesian migrant workers were decorated by Indonesian cultural style. When migrant workers enter these centers, they feel at home, comfortable and relax. Thai-Families are actually "migrant worker churches" with their own Thai-speaking pastors and congregations. These homes/families, liking the "Cities of Refuge" in the Old Testament, offer safe and comfortable shelters for innocent migrant workers. ${ }^{17}$ The Church and church-related institutes aim to build a bridge of dialogue between migrant workers and governmental offices, between employees and employers. Lan Anh Hoang is right to argue that a well-formed social network is a great blessing of social capital. ${ }^{18}$ In this sense, Church's ministry is meaningful in playing the role of home, family and bridge to weave the social network for migrant workers. We have to confess that the ministry for migrant workers from Christian Church is still not strong enough at the present-day. However, it is gratifying that more and more local churches join the ally to respond the plight of migrant workers.

\section{Theological reflection on the problem of migrant workers}

Compare to other religions (Buddhism, Taoism, Confucianism...etc..), Christians (both of Catholic and Protestant) are minority in Taiwan; however, they are more active and positive in doing ministry for migrant workers.

17 The cities of Refuge refer to six towns, Golan, Ramoth, Bosor, Kedesh, Shechem, and Hebron. (Deuternomy,19:1-14; Joshua, 20:1-7) in the ancient Israel which the perpetrators of accidental manslaughter could claim the right of asylum. Metaphorically, it means a safe place for those innocent but oppressed people.

Bible names the six cities as being cities of refuge: Golan, Ramoth, Bosor, Kedesh, Shechem, Hebron.

18 Cf. Lan Ahn Hoang, "Vietnamese migrant networks in Taiwan: the curse and boon of social capital," In Ethnic and Racial Studies 2016, Vol. 39, No.4, pp. 690-707. According to Hoang, social network can offer a vital source of material and psychological support as well as a platform where relationships are developed, sustained and contested. "It reveals both productive and destructive potentials of social capital in situations where the migrant labourer becomes a disenfranchized underclass and their radius of trust is unsettled by physical displacement.” (Ibid., p.690) Hoang use the theory of Social capital of Bourdieu who defines social capital as "the aggregate of the actual or potential resources which are linked to possession of a durable network of more or less institutionalized relationships of mutual acquaintance and recognition'. In his theorization of social capital, Bourdieu emphasizes the convertibility of social connections to economic capital and vice versa." (Ibid., p.692) 
They concern migrant workers because they want to follow the teaching of the Bible and inspired by the love of Jesus. The Bible manifests that God is A Migrant God and God's People is a migrant people. The experience of migrant worker is the resource for doing theology. To respond to the plight of migrant workers is an indicator of the churches self-understanding of the missio Dei. ${ }^{19}$ David Bosch is right to point out that " $[\mathrm{M}]$ ission has its origin in the heart of God. God is the fountain of sending love. This is the deepest source of mission. It is impossible to penetrate deeper still; there is mission because God loves people." (BOSCH, 1991, p. 392) The Presbyterian Church of Taiwan (PCT), led by contextual theologians such as Shoki $\mathrm{Coe}^{20}$ and C. S. Song, emphasizes the importance of practicing mission Dei in Taiwanese context. From the contextual theology for doing missio Dei, we can interpret the meanings of the ministry for migrant worker as follow.

\section{To do justly to Migrant workers}

"He has shown you, O mortal, what is good. And what does the LORD REQUIRE OF YOU? TO ACT JUSTLY AND TO LOVE MERCY AND TO WALK HUMBLY with your God.” (Micah, 6:8, NIV) This verse cited from Prophet Micah is one of most important biblical teaching concerning the social ethics of Christianity. Church and Christian are called by God to do justly to everyone, especially to struggle justice for the marginalized and suffering people.

As human being, there is no doubt at all that every migrant worker has his/her basic human rights. "[T] o deny people their rights before the Most High, to deprive them of justice — would not the Lord see such things?" (Lamentation 3:35-36, NIV). The Lord concerns human rights as a matter of justice. How to use the labor force of migrant workers is a topic of economic, but how to treat them as "persons" is an issue of social ethics. A migrant worker is not a "thing," but a "person" with human dignity. From the

19 Cf. Robert T. Hamd, Migrant domestic workers, the Church, and mission. (Dissertations Publishing), p. 5. Hamd's dissertation discussed the migrant domestic workers in Lebanon, but his observation is similar as in Taiwan.

Available online at ctx_ver=Z39.88-2004\&ctx_enc=info\%3Aofi $\% 2 F e n c \% 3 A U T F-8 \& r f r \_$ id $=$ info $\% 3$ Asid $\% 2$ Fsummon.serialssolutions.com\&rft_val_fmt.

20 Shoki Coe ( $\mathrm{Ng}$ Chiong-hui; 1914-1988) was a pastor of the Presbyterian Church in Taiwan. He was the principal of Tainan Theological Seminary and director of the Theological Education Fund of the World Council of Churches. He is the one who coined the term "Contextualization," and encouraged the development of contextual theology: doing theology in responding to the sociopolitical concerns of a local context. 
perspectives of Creation Story in Genesis, human being was created in the image of God (imago Dei); from the perspective of redemption, every man is to be loved and to be redeemed by Jesus Christ, who had been crucified on the Cross. Migrant workers have their dignity as human beings that should not be humiliated, their human rights should not be deprived. They are members of civil society who contribute economic development and cultural pluralism. They are from foreign countries, but they are brothers and sisters in the global family of the world, especially in the household (oikos) the Lord. They have the rights of free choice, reasonable payment, holidays, equal treatment, safety and healthy work conditions. Whenever their rights were deprived, the Lord who is just will concern and send His servants to help them.

When the ancient Israelite, who were once migrant workers in Egypt, cried to the Lord for their miserable situation. The Lord said, "I have indeed seen the misery of my people in Egypt. I have heard them crying out because of their slave drivers, and I am concerned about their suffering. So I have come down to rescue them from the hand of the Egyptians and to bring them up out of that land into a good and spacious land, a land flowing with milk and honey." (Exodus, 3:7-8, NIV) God, who has no favoritism to all nations and all people in his salvation in Jesus Christ (Roman, 2:11, NIV), must have seen the misery and heard the crying of the migrant workers, and send out His servants to rescue those marginalized and suffering people.

\section{To be Compassionate to migrant workers}

The Lord is "the compassionate and gracious God, slow to anger, abounding in love and faithfulness." (Exodus 34:6) To be merciful and compassionate to suffering people is the principle and fountain of Christian social work. Jesus said, "[J]ust as the Son of Man did not come to be served, but to serve, and to give his life as a ransom for many." (Matthew, 20:28, NIV) Jesus Himself is the best example. In 1989, Chinese Regional Bishop's Conference in Taiwan declared publically, "One of main mission of church is to take care of the people in poverty and plight, to speak for the vulnerable, and to be the bridge between the government and employers. We have to face and to solve the problems of migrant workers with the spirit of brotherhood and the commandment "love your neighbor as yourselves." 21

21 "A Report of Workshop for Caring Migrant Family," in Catholic Monthly, Vol. 157, p.5. See http://www.catholic.org.tw/catholicweekly/archive/archive/Catholic\%20Weekly_157, accessed 3 October, 2017. 
To practice divine love has to avoid any discrimination of gender, race, nationality and class. The Gospel of the Lord is for all human beings, and in Christ "there is no Gentile or Jew, circumcised or uncircumcised, barbarian, Scythian, slave or free, but Christ is all, and is in all." (Colossian 3:11, NIV). It is imperative for Christian to serve others, especially to care the vulnerable. Jesus' parable of "the Sheep and the Goats" (Matthew 25:31-46, NIV) explains the very reason why to care migrant workers in the context of Taiwan is an unavoidable responsibility for Christian. It reads,

"When the Son of Man comes in his glory, and all the angels with him, he will sit on his glorious throne. All the nations will be gathered before him, and he will separate the people one from another as a shepherd separates the sheep from the goats. He will put the sheep on his right and the goats on his left. "Then the King will say to those on his right, 'Come, you who are blessed by my Father; take your inheritance, the kingdom prepared for you since the creation of the world. For I was hungry and you gave me something to eat, I was thirsty and you gave me something to drink, I was a stranger and you invited me in, I needed clothes and you clothed me, I was sick and you looked after me, I was in prison and you came to visit me." "Then the righteous will answer him, 'Lord, when did we see you hungry and feed you, or thirsty and give you something to drink? When did we see you a stranger and invite you in, or needing clothes and clothe you? When did we see you sick or in prison and go to visit you?' The King will reply, 'Truly I tell you, whatever you did for one of the least of these brothers and sisters of mine, you did for me.' Then he will say to those on his left, 'Depart from me, you who are cursed, into the eternal fire prepared for the devil and his angels. For I was hungry and you gave me nothing to eat, I was thirsty and you gave me nothing to drink, I was a stranger and you did not invite me in, I needed clothes and you did not clothe me, I was sick and in prison and you did not look after me.' They also will answer, 'Lord, when did we see you hungry or thirsty or a stranger or needing clothes or sick or in prison, and did not help you?' $\mathrm{He}$ will reply, 'Truly I tell you, whatever you did not do for one of the least of these, you did not do for me.' Then they will go away to eternal punishment, but the righteous to eternal life."

To care the vulnerable, the foreigners and the needed is essential to Jesus' teaching on the Kingdom of God. It is glad to see that some local churches in Taiwan have established centers of temporary shelters for migrant workers and practice Jesus' teaching. For example, Stella Maris International, Kaobsiung has sheltered at least more than 2000 migrant workers from 1996 
up to now. A new center of shelter is going to be built in order to provide more convenient and emergent service for migrant workers.

Father Peter Nguyen from Vietnam, the director of Hope Workers' Center in Shin-chu, served migrant workers for more than 20 years. He fights for the human rights of the migrant workers and for the sake of justice. He cannot bear the in-human treatment that the government, broker and employer had done to migrant workers. He said, "In daily life, I and Taiwanese are just like a family. The people and the land make me feel comfortable. But if Taiwanese people can treat migrant workers from Vietnam and other Southeast Asia countries more humanitarian and more compassionately, I will cheer for Taiwan."22

\section{To be hospitable to migrant workers}

Migrant workers should be treated compassionately and justly, and they deserve to be treated with hospitality. To be hospitable to foreigners is kind of virtue in Christian ethics.

The story of Abraham and the three foreign guests by the oaks of Mamre (Genesis, 18:1-15, NIV) and the Lot received and protected his two guests in Sodom (Genesis, , 19: 1-38, NIV) are two good instances of hospitability. ${ }^{23}$ The author of Epistle to the Hebrews used Abraham and Lot as examples to exhort his readers, "Do not forget to show hospitality to strangers, for by so doing some people have shown hospitality to angels without knowing it." (Hebrews, 13:2, NIV)

22 Hui-Sin Chang, "Bring hope and faith to the migrant workers: interview with Father Peter Nguyen" this article is an interview to Peter Nguyen when he was awarded by the TECO Technology Foundation due to his great contribution on caring migrant workers. Here Chinese translation is mine. See http://blog.xuite.net/tecofound/blog/29473432$\% \mathrm{E} 7 \% 82 \% \mathrm{BA} \% \mathrm{E} 7 \% \mathrm{~A} 7 \% \mathrm{BB} \% \mathrm{E} 5 \% \mathrm{~B} 7 \% \mathrm{~A} 5 \% \mathrm{E} 7 \% \mathrm{~A} 7 \% \mathrm{BB} \% \mathrm{E} 6 \% \mathrm{~B} 0 \% 91 \% \mathrm{E} 5 \% \mathrm{~B} 8 \% \mathrm{~B} 6$ $\% \mathrm{E} 4 \% \mathrm{BE} \% 86 \% \mathrm{E} 5 \% \mathrm{~B} 8 \% 8 \mathrm{C} \% \mathrm{E} 6 \% 9 \mathrm{C} \% 9 \mathrm{~B} \% \mathrm{E} 5 \% 92 \% 8 \mathrm{C} \% \mathrm{E} 4 \% \mathrm{BF} \% \mathrm{~A} 1 \% \mathrm{E} 5 \% \mathrm{BF} \% 83$ $\% \mathrm{E} 5 \% \mathrm{~B} 0 \% 88 \% \mathrm{E} 8 \% \mathrm{~A} 8 \% \mathrm{AA} \% \mathrm{E} 9 \% 98 \% \mathrm{AE} \% \mathrm{E} 6 \% 96 \% 87 \% \mathrm{E} 9 \% 9 \mathrm{~B} \% 84 \% \mathrm{E} 7 \% \mathrm{~A} 5 \% 9 \mathrm{E} \%$ E7\%88\%B6/ accessed 10 August 2017, Here chiense translation is mime.

"Now the Lord appeared to him by the oaks of Mamre, while he was sitting at the tent door in the heat of the day. When he lifted up his eyes and looked, behold, three men were standing opposite him; and when he saw them, he ran from the tent door to meet them and bowed himself to the earth, and said, 'My lord, if now I have found favor in your sight, please do not pass your servant by. Please let a little water be brought and wash your feet, and rest yourselves under the tree; and I will bring a piece of bread, that you may refresh yourselves; after that you may go on, since you have visited your servant.' And they said, 'So do, as you have said"' (Gen 18,1-5, NIV). 
When Moses was exiled to Midian, he was well treated by Jethro. Jethro gave his daughter Zipporah to Moses in marriage. Zipporah gave birth to a son, and Moses named him Gershom, saying, "I have become a foreigner in a foreign land." (Exodus 2:21-22) Probably the migrant experience in foreign land influenced Moses deeply, so that in the Five Books of Moses (the Torab) the rights of strangers were well respected and emphasized:

The same law applies both to the native-born and to the foreigner residing among you. (Exodus 12:49; Leviticus 24:22, NIV)

Do not mistreat or oppress a foreigner, for you were foreigners in Egypt. (Exodus 22:21, NIV)

Do not oppress a foreigner; you yourselves know how it feels to be foreigners, because you were foreigners in Egypt. (Exodus 23:9, NIV)

When a foreigner resides among you in your land, do not mistreat them. The foreigner residing among you must be treated as your native-born. Love them as yourself, for you were foreigners in Egypt. I am the LORD YOuR GOD. (Leviticus 19:33-34, NIV

Six days do your work, but on the seventh day do not work, so that your ox and your donkey may rest, and so that the slave born in your household and the foreigner living among you may be refreshed. (Exodus 23:12, NIV) When you reap the harvest of your land, do not reap to the very edges of your field or gather the gleanings of your harvest. Leave them for the poor and for the foreigner residing among you. I am the LonD your God. (Leviticus $23: 22, \mathrm{NIV}$ )

These teachings on hospitability in Five Books of Moses, were inherited by the Prophets and Apostles. For example, prophet Ezekiel proclaimed, "You are to allot it as an inheritance for yourselves and for the foreigners residing among you and who have children. You are to consider them as native-born Israelites; along with you they are to be allotted an inheritance among the tribes of Israel. (Ezekiel 47:22, NIV). Apostle Paul exhorted, "Share with the Lord's people who are in need. Practice hospitality." (Romans 12:13, NIV) "Now the overseer is to be above reproach, faithful to his wife, temperate, self-controlled, respectable, hospitable, able to teach, not given to drunkenness, not violent but gentle, not quarrelsome, not a lover of money." (I Timothy 3:2, NIV) The author of Epistle to the Hebrews pointed out that the true believers "admitting that they were foreigners and strangers on earth." (Hebrews 11:13, NIV) When one confesses that he/ she is just like a foreigner and stranger in this world, then he/she would be more compassionate to migrant workers. 


\section{The contributions of migrant workers could be beyond expectation}

According to the Old Testament, the ancient Israelite is a migrant people. Many famous role models of Christian faith were migrant workers of their times. For example, Abraham migrated from Ur of the Chaldeans to Canaan. Jacob migrated from Canaan to Harran near the Rive Euphrates. Joseph migrated, sold by his brother, to Egypt and worked for Pharaoh. Daniel migrated, by exiled, to Babylon and worked for the emperor Nebuchadnezzar.

Among them, the story of Joseph was the most famous and inspiring. Joseph was sold by his own brothers first to a Midian and then to an Egyptian. He suffered the misery of human trafficking. He was almost raped by his seductive mistress. He was put into prison because of false accusation. He was forgotten by those whom he helped. However, after all of these miserable migrant experiences, he succeeded and became the prime minister of Pharaoh. As a migrant worker he helped his employer solved many thorny problem, including of famine. (Exodus, 41:1-57)

The story of Joseph reminds us that how miserable experiences a migrant worker might encounter and what remarkable achievement he/she might contribute. To treat kindly to migrant workers will bring blessings to the country; on the contrary, to treat them badly would lead to curses. The Pharaoh who treated Joseph kindly solved the problem of famine by the help of Joseph. The Pharaoh who treated the people of Israel as cheap and non-personal migrant workers caused destructive calamity to Egypt. The Lord sent Moses to lead those Israelite who became migrant slaves to leave Egypt and enter into the promised land, and those who exploited migrant workers were punished by plagues.

In past forty years, migrant workers left their countries and families to work in Taiwan. They sacrificed their youth, shed their tear and blood, to contribute Taiwan in public works, industrious production and home care. The development and commonwealth of Taiwan today was contributed by corporate efforts of all classes, all communities and all ethnicities, including that of migrant workers. They are worthy to be treated with fairness and respect rather than exploit and discrimination.

Besides of economic development, migrant workers could also have contribution in cultural dimension. The cultures of Philippines, Thailand, Indonesia, and Vietnam began were brought into Taiwan by migrant workers 
and inject new elements and vigor into the civil society of Taiwan. It is worth noting that several NGOs try to take a "cultural strategy" to sever migrant works. They promoted cultural programs, like poem, music, literature and dancing to introduce the cultures of migrant workers to Taiwanese society. "The Literature Award for Migrants" sponsored by Chinese Association for Foreign Spouses and Labors' Voice is one of good examples. Those entries of Award revealed the fear and the hope of migrant workers, reflected the cruel and kindness of Taiwanese society. Professor Fang-Ming Chen, a famous writer of Taiwanese Literature, commented cogently, "The literary works that can express the feeling and the memory that happen on the Land of Taiwan belong to Taiwanese Literature, no matter where do their authors come from." 24 The literary works of migrant workers become a new element of Taiwanese Literature. Arguably, Migrant worker can contribute to cultural and religious dialogue and to achieve communion in diversity in Taiwan.

Most Taiwanese are descendants of migrant workers, most of our ancestors migrated from ancient China. Today, migrant workers continue to bring new elements of different language and different historical memory to Taiwan to widen and to enrich our traditional culture. Whenever Taiwanese regard migrant workers not as outside strangers but as brothers and sisters in the extended family of Taiwan, then their contributions would go beyond our expectations. "To help migrant workers is not to pity them but to help ourselves and to prove that Taiwan is a society of justice and equality." ${ }^{25}$

\section{Concluding Remarks}

For a long time, Taiwan was marginalized in the international society because of tensions with the People's Republic of China (PRC). Today, only a handful of countries (exactly 18) maintain official diplomatic ties with Taiwan. The marginalized situation of Taiwan is worse by the intensifying threat and oppression from PRC. The dominant political issue is cross-strait relations,

24 Feng Ming Chen's address in the Ceremony of "The Literature Award for Migrants." Please see Zou Du-Sho, China Newletters, May 17, 2014.

25 The address of Hsiao-Chuan Hsia, the founder of TransAsia Sisters Association, Taiwan (TASAT), in Ceremony of TECO AWARD afforded by TECO Technology Foundation in Nov. 11, 2009. See http://blog.xuite.net/tecofound/blog/29474908$\%$ E7\%AC $\%$ AC $\%$ E5\%8D $\% 81 \%$ E5\%85\%AD $\%$ E5\%B1\%86\%E6\%9D $\%$ B1\%E5\%85\%83 $\%$ E7\%8D $\% 8 \mathrm{E} \% \mathrm{E} 9 \% 9 \mathrm{~A} \% 86 \% \mathrm{E} 9 \% 87 \% 8 \mathrm{D} \% \mathrm{E} 9 \% \mathrm{~A} 0 \% 92 \% \mathrm{E} 7 \% 99 \% \mathrm{BC} \% \mathrm{EF} \% \mathrm{BC} \% 8 \mathrm{C}$ $\% \mathrm{E} 4 \% \mathrm{BA} \% \mathrm{BA} \% \mathrm{E} 6 \% 89 \% 8 \mathrm{D} \% \mathrm{E} 5 \% \mathrm{AF} \% \mathrm{~B} 6 \% \mathrm{E} 5 \% \mathrm{BA} \% \mathrm{AB} \% \mathrm{E} 6 \% \mathrm{~A} 8 \% \mathrm{~B} 9 \% \mathrm{E} 7 \% \mathrm{AB} \% 8$ B $\%$ E5\%85\%B8\%E7\%AF\%84/ accessed 10 August 2017. 
it divides the people who live in Taiwan into two conflicting groups, proreunification versus pro-independence. While a strong majority of Taiwanese citizens favor maintenance of the current status quo with China, "a détente the United States has supported since the 1970's, Taiwan's position between China and the United States is only becoming more precarious." ${ }^{26}$ As Taiwanese, we experience the suffering of being marginalized by international political games, we should learn much through this suffering of being marginalized and become more sensitive and supportive to those who are marginalized in Taiwan's context. The marginalized migrant workers in Taiwan should be one of our premium concerns and missions.

The Golden Rule of social ethics found in the teaching of Jesus might help Taiwanese get rid of misfortune of marginalization. "So in everything, do to others what you would have them do to you, for this sums up the Law and the Prophets." (Matthew 7:12, NIV) If we practice the Golden Rule to migrant workers, to accept them rather than to marginalize them, to treat them with hospitality rather than exploit and discrimination. If we do justly and have mercy for them, we might be treated justly in international society and be loved by the merciful God. In helping migrant workers, we help ourselves. Jesus means marginalized people who suffered economic exploitation, political oppression and cultural discrimination and social exclusion. The Gospels witnessed that Jesus lived among the marginalized people, served them and died for them. The parable of "the Sheep and the Goats" explains that Jesus identifies Himself with marginalized people. Whatever we do for them is to do it for Jesus, and whatever we do not for them is not to do it for Jesus. The way we treat migrant workers will return to our own future, either blessings or curses. It is encouraging that more and more churches in Taiwan regard the ministry for migrant workers as one of missio Dei in the context of Taiwan. To awake more Christians and Taiwanese people to join the ally for caring migrant workers is our urgent mission today.

\section{Acknowledgements}

I would like to thank Chang Jung Christian University, Tainan, Taiwan and Georgetown university, Washington D. C. USA. From February 2018 to January 2019, I got a sabbatical year form CJCU and was accepted as a research scholar to GTU hosted by Professor Peter Phan.

26 Daniel Runde, "Taiwan Is A Model Of Freedom And Prosperity", in FORBES website, 26 MAY 2015. https://www.forbes.com/sites/danielrunde/2015/05/26/taiwan-developmentmodel-freedom-prosperity/\#68ff98b4670c/ accessed 1 June 2018. 


\section{Disclosure statement}

No potential conflict of interest was reported by the author. Funding

This article is one of results of the author's research project titled "Dialogue between Context and Text (2): Taiwan's Contextual Theology and Contemporary Theological Hermeneutics." (106-2410-H-309-016-) granted by the Ministry of Science and Technology (MOST), Republic of China.

\section{References}

BOSCH, David, Transforming Mission: Paradigm Shifts in Theology of Mission, American Society of Missiology series; no. 16. Maryknoll, NY: Orbis Books. 1991.

CHOLEWINSKI, Ryszard, et al., Migration and Human Rights: The United Nations Convention on Migrant Workers' Rights, Cambridge University Press, 2009.

HAMD, Robert T., Working with Migrant Domestic Workers in Lebanon (1980-2012): A Mapping of NGO Services Beirut, International Labour Organization, 2012. (Dissertations Publishing), Available online at ctx_ver=Z39.88-2004\&ctx_enc=info $\% 3$ Aofi $\% 2 F e n c \% 3$ AUTF-8\&rfr_ id $=$ info $\% 3 \mathrm{Asid} \% 2$ Fsummon.serialssolutions.com\&rft_val_fmt.

HOANG, Lan Anh, Moral Dilemmas of Transnational Migration: Vietnamese Women in Taiwan. In Gender and Society (2016) Vol.30, No.6.

LIU, Wen, The embodied crises of neoliberal globalization: The lives and narratives of Filipina migrant domestic workers. In Women's Studies International Forum (2015) Vol.50.

MOON, Cyris H.S., A Korean Minjung Theology. Hong Kong: Pliugh Publications, 1985.

Pope John Paul II, “Address on the $87^{\text {th }}$ Day of International Migrant Worker."( 2001) Cited from http://www.hkjp.org/files/files/focus/humanright/2001_87\%27_immigrant_\%20 refugee_\%20statement.pdf. Accessed 10 January 2018.

SONG, Choan-Seng, Jesus, the Crucified People. Minneapolis: Fortress Press, 1990.

TARAN, Patrick A., "The need for a rights-based approach to migration in the age of globalization," in CHOLEWINSKI, Ryszard, et al. Migration and Human Rights: The United Nations Convention on Migrant Workers' Rights. Cambridge University Press, 2009.

TSENG, Yen-fen \& HONG-zen Wang, Governing Migrant Workers at a Distance: Managing the Temporary Status of Guestworkers in Taiwan, in International Migration (2013), Vo.51, No. 4.

YANG, Ming-Jen, SHIH, Chun-Hwa and others, "The Problem of Accommodation of Migrant Workers in Taiwan" in Formosa Journal of Mental Health (1999), vol. 12. no.1. 


\section{Website news}

“A Report of Workshop for Caring Migrant Family," in Catholic Monthly, Vol. 157, p.5. See http://www.catholic.org.tw/catholicweekly/archive/archive/Catholic\%20Weekly_157, accessed 3 October, 2017.

BBC News, published on 17 September 2017, https://www.bbc.com/news/world-asia-41298076, accessed June 16, 2018.

“KRTC Scandal: Workers' riot ends up reshaping politics" in Taipei News website: http://www.taipeitimes.com/News/taiwan/archives/2005/11/07/2003279103 accessed 16 June 2018.

"Migrant workers right in Taiwan: An Interview with The Taiwan International Workers Association" (TIWA). In the Blog, Nihao's Going, https://nihaositgoing.com/2017/11/07/ migrant-worker-rights-in-taiwan-an-interview-with-the-taiwan-international-workers-associationtiwa/ accessed 16 June 2018.

"New documentary unveils the life of Vietnamese migrant workers in Taiwan." Taiwan News, March 20, 2018. https://www.taiwannews.com.tw/en/news/3386443, accessed 10 June 2018.

South China Morning Post, published on 20 September, 2017 http://www.scmp.com/news/china/ policies-politics/article/2111965/group-fishermen-kept-slaves-taiwan, accessed 14 June 2018.

"Table of Workers in Productive Industries and Social Welfare by Nationality," Workforce Development Agency, Ministry of Labor, Taiwan. http://statdb.mol.gov.tw/statis/jspProxy. px? sys $=220 \& y \mathrm{~m}=10504 \& \mathrm{ymt}=10704 \& \mathrm{kind}=21 \&$ type $=1 \&$ funid $=\mathrm{q} 13012 \& \mathrm{cycle}=41 \&$ outmo $\mathrm{de}=0 \& \&$ compmode $=0 \&$ outkind $=11 \&$ fldspc $=0,8, \& \mathrm{rdm}=\mathrm{V} 4 \mathrm{nVIjtg} /$ Accessed 6 June 62018. 